\title{
STATISTIEK DER MISDRIJVEN IN DE STAD NEW-YORK VAN 1880 TOT EN MET 1889.
}

Bij de niet zelden ook hier te lande voorkomende klachten over onvoldoende handhaving van orde en veiligheid in de groote centra van bevolking, is het niet zonder belang kennis te nemen van een verslag door den „Board of Police Justices" te New-York in de maand Juli van dit jaar uitgegeven, waarin het aantal politie-strafvonnissen over het afgeloopen jaar wordt vergeleken met dat over 1880 . Het resultaat is als volgt:

ARRESTS FOR FELONIOUS ASSAULT. (Verraderlijke aanranding).

\begin{tabular}{|c|c|c|c|c|c|c|c|c|}
\hline 1880 & . & . & - & • & - & $\begin{array}{r}\text { Male. } \\
561\end{array}$ & $\begin{array}{c}\text { Female. } \\
\quad 49\end{array}$ & $\begin{array}{r}\text { Total. } \\
610\end{array}$ \\
\hline \multirow[t]{3}{*}{1889} & . & . & • & & & 557 & 44 & 601 \\
\hline & & & $\Delta R R$ & STB & Fo & BURGLAI & (Inbraak). & \\
\hline & & & & & & Male. & Female. & Total. \\
\hline 1880 & . & - & . & . & & 775 & 48 & 824 \\
\hline \multirow[t]{3}{*}{1889} & . & . & . . & . & & 758 & 11 & 769 \\
\hline & & & $\mathbf{A R R}$ & $\mathrm{as} \mathrm{T}$ & $\mathrm{FC}$ & $\angle \triangle B C E N$ & (Diefstal). & \\
\hline & & & & & & Male. & Female. & Total. \\
\hline 1880 & . & - & . & . & . & 1,347 & 340 & 1,687 \\
\hline \multirow[t]{3}{*}{1889} & . & . & . & . & . & 1,554 & 293 & 1,847 \\
\hline & & & RESTS & Fo & & CEIVING $\mathrm{s}$ & WEN PROPER? & \\
\hline & & & & & & Male. & Female. & Total. \\
\hline 880 & . & . & . & & & 72 & 12 & 84 \\
\hline 1889 & . & . & . & & . & 56 & 4 & 59 \\
\hline
\end{tabular}

ARRESTS FOR SIMPLE ASSAULT. (Eenvoudige aanranding).

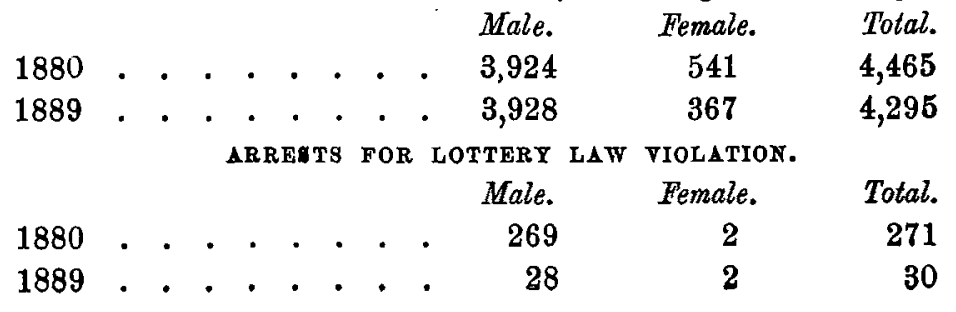


ARRESTS FOR PETIT LARCENY. (Kleine diefstallen).

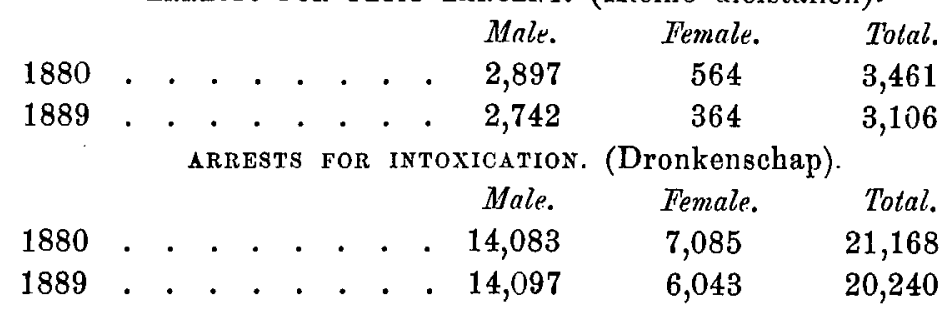

Derhalve is het aantal politie-strafvonnissen gedurende de laatste tien jaren verminderd met 928. Op zich zelf is die vermindering niet van veel belang, maar zij verkrijgt groote beteekenis, wanneer rekening wordt gehouden met de omstandigheden waaronder zij plaats vond.

Vooreerst bedroeg de bevolking der stad in 1880 ongeveer $1,200,000$ zielen, in $1889: 1,600,000$. De toename was dus circa 400,000 personen en dat niettemin het aantal misdrijven daalde, trekt vooral de aandacht wanneer men bedenkt uit welke elementen de nieuwe bevolking voor een anmerkelijk deel bestond. Daaronder bevonden zich toch talrijke Europeesche emigranten, die zonder twijfel tot de gevaarlijke klassen behoorden en hun vaderland verlieten omdat zij zich door hun wangedrag de gelegenheid hadden benomen aldaar tot een beteren toestand te geraken. Gelijk bekend is, heeft men eerst in den allerlaatsten tijd een scherper toezicht op het gehalte der landverhuizers ingevoerd en er somtijds zelfs terug gezonden, ten deele ook omdat zooveel van de slechtere elementen te New-York bleef hangen.

Vervolgens valt hier niet te denken aan verslapping van het politie-toezicht, waardoor vele misdrijven ongestraft zouden blijven. Integendeel is dat toezicht in die jaren zeer verscherpt en is de organisatio der New-Yorksche politie allengs zoo goed geworden dat $z \mathrm{ij}$ aan de meeste andere steden ten voorbeeld mag worden gesteld en tegenwoordig niet alleen bij deskundigen maar ook bij leeken als voortreffelijk ingericht bekend staat.

Waarschijnlijk ligt juist in die goede inrichting on scherp teezicht een der voornaamste oorzaken waardoor misdrijven worden voorkomen en de vermindering is te verklaren.

Er zijn er echter nog andere, niet minder belangrijk. Als een der voornaamste redenen wordt genoemd dat eenerzijds de arbeidsloonen zijn gestegen, terwijl tevens de koopkracht van het als loon uitbetaalde geld is toegenomen. Een Amerikaansch axbeider ontvangt thans in goud minstens evenveel als hij in den eersten 
tijd na den burgeroorlog ontving in „inflated currency." Hij koopt daarvoor van sommige levensbehoeften tweemaal zooveel, van andere de helft of een derde meer dan toenmaals. Men moet terug gaan tot de jaren vóor den oorlog om een tijd te vinden dat het geld eene even groote koopkracht had als thans, maar toen waren de arbeidsloonen slechts de helft van de tegenwoordige. Eerst zijn, tengevolge der verminderde koopkracht van het papieren geld door den gedwongen koers, de loonen gerezen, en toen later het geld weder in waarde toenam, zijn zij op dezelfde hoogte gebleven. Deze blijvende vermeerdering van inkomsten beeft niet alleen geleid tot eene verhooging van den materieelen levensstandaard maar ook tot vermeerdering van het gevoel van eigenwaarde en tot een opgewekter levensbeschouwing. Tegenspoed en moedeloosheid leiden tot misdrijf, hetzij door verbittering of onverschilligheid of door tusschenkomst van drankmisbruik, terwijl ruime loonen het vertrouwen van den arbeider en zijn gezin op de tookomst versterken.

Volgens hetgeen, althans in New-York, uit waarnemingen gedurende de laatste 15 jaren is gebleken, zou vermeerdering van loon, gepaard met vermindering van werkuren, in zedelijk, verstandelijk en maatschappelijk opzicht zeer gunstig op de arbeidende klasse hebben gewerkt.

Eene andere oorzaak der verbetering wordt gezocht in het volksonderwijs. Wel is dit op zich zelf geen panacée tegen alle maatschappelijke kwalen, maar toch is de invloed van het geregeld schoolbezoek en de voortdurende aanraking met kinderen uit ordelijke gezinnen zeer goed waarneembaar op de duizende kinderen die, bij gebrek an een voldoend aantal goed ingerichte scholen, het grootste gedeelte van den dag op straat of elders aan allerlei verkeerde invloeden blootstonden. De scholen beveiligen de kinderen tegen het kwaad, niet alleen door hetgeen zij or leeren, maar ook door de omgeving waarin zij worden geplaatst, in tegenstelling met die waaraan $z \mathrm{ij}$ voor een groot deel van den dag worden onttrokken.

Eindelijk hebben niet weinig tot vermindering der misdrijven bijgedragen de verschillende philanthropische instellingen die, gelijk bekend is, in de Vereenigde Staten op zeer vitgebreide schaal, met ruime middelen en groote toewijding werkzaam zijn. Bepaaldelijk mag hier genoemd worden: Mr. Brace's Childrens Aid Society, eene krachtige vereeniging, die duizende kinderen heeft onttrokken niet alleen aan de straat, maar ook, somtijds met veel inspanning, aan ongezonde woningen en eene gedemoraliseerde 
omgeving om ze over te brengen naar gezinnen waar zij in begrippen van orde en plichtsbetrachting worden opgevoed en in de gelegenheid gesteld een behoorlijk beroep aan te leeren en later uitteoefenen. Het ligt voor de hand dat deze beperking van het aantal jeugdige vagebonden beperkend werkt op de overtredingen der wet, vooral in toekomstige jaren. Het verslag der Police Justices is ongetwijfeld zeer anmoedigend voor hen die philanthropische instellingen door gift of daad steunen, omdat daaruit blijkt dat hunne pogingen niet vruchteloos zijn. Maar ook in ruimeren kring is deze statistiek niet onbevredigend. Immers wanneer het mogelijk is het peil van zedelijkheid en welvart to doen stijgen in eene stad als New-York, die alle ongunstige voorwaarden der groote steden in zich vereenigt en daarenboven een trechter is waarin zich vele bedorven elementen van andere landen verzamelen, dan is hetzelfde resultaat, onder normale economische omstandigheden en bij eene doelmatige inrichting van politie, volksonderwijs en philanthropische instellingen, overal elders bereikbaar. Bij de pessimistisch-fatalitische leer die tegenwoordig veclal wordt verkondigd, kan het nuttig zijn hierop te wijzen. 